\title{
Catalytic activity of low cost materials for pollutants abatement by Fenton's process
}

\author{
Rui C. Martins, Lucy R. Henriques, Rosa M. Quinta-Ferreira* \\ CIEPQPF-Chemical Engineering Processes and Forest Products Research Center, GERSE, Group on Environment, Reaction and Separation Engineering, \\ Department of Chemical Engineering, Faculty of Sciences and Technology, University of Coimbra, Pólo II-Rua Sílvio Lima, 3030-790 Coimbra, Portugal
}

\section{H I G H L I G H T S}

- Low cost materials were tested as catalysts in Fenton's process.

- Iron shavings were selected as most active for synthetic and real OMW treatment.

- Process was efficient both in batch and continuous conditions.

- Biodegradability was enhanced and eco-toxicity was depleted.

- This methodology integrates waste management and wastewater treatment.

\section{A R T I C L E I N F O}

\section{Article history:}

Received 3 September 2012

Received in revised form

26 February 2013

Accepted 14 March 2013

Available online 25 March 2013

\section{Keywords:}

Low cost catalysts

Environment

Fenton's process

Leaching

Multiphase reactors

Pollution

\begin{abstract}
A B S T R A C T
The main objective of this study was to investigate the catalytic activity of three low cost materials (sepiolite, red volcanic rock and iron shavings) during the Fenton-like process on the treatment of simulated and actual olive mill wastewaters. Among the catalysts screened, iron shavings (ZVI) was the most promising, as it was the catalytic material that attained the best performance. Besides it as the advantage of being a waste of iron processing industry, not needing any modification before use. Since the Fenton's reaction efficiency is dependent on ZVI and $\mathrm{H}_{2} \mathrm{O}_{2}$ concentrations and as well as initial pH, the effect of these parameters was analyzed in batch tests for a synthetic phenolic effluent treatment. From the results it was concluded that the most interesting removals (94\% of TPh, 54\% of COD and 60\% of TOC) were reached using $[\mathrm{ZVI}]=40 \mathrm{~g} / \mathrm{L},\left[\mathrm{H}_{2} \mathrm{O}_{2}\right]=35 \mathrm{mM}$ and $\mathrm{pH}=3$. This effectiveness was confirmed when Fenton's peroxidation under the same conditions was applied to an actual olive mill wastewater (OMW). The impact of this methodology over the effluents biodegradability and toxicity was still grasped.

Furthermore, the stability of ZVI under continuous conditions was also tested when applied to both the synthetic phenolic effluent and real OMW treatments in a fixed bed reactor using the $\mathrm{H}_{2} \mathrm{O}_{2}$ load and $\mathrm{pH}$ optimized in batch reaction; high activity was still observed after $168 \mathrm{~h}$ of operation of the column when synthetic phenolic effluent was treated, since TPh, TOC and COD removals remained about 73\%, $39 \%$ and $44 \%$, respectively. These results show that ZVI can be used as low cost catalytic material in Fenton reaction for the treatment of OWM in batch or continuous reaction with high catalytic stability. (c) 2013 Elsevier Ltd. All rights reserved.
\end{abstract}

\section{Introduction}

One of the most important scopes of chemical reaction engineering nowadays is devoted to environment protection. In fact, industry generates large amounts of wastewaters usually incorporating huge pollutant loads which, if directly discharged throughout the natural water bodies, threaten the ecosystems and therefore the

\footnotetext{
${ }^{*}$ Corresponding author. Tel.: +351 239798723; fax: +351239798703.

E-mail addresses: martins@eq.uc.pt (R.C. Martins), rosaqf@eq.uc.pt (R.M. Quinta-Ferreira).
}

life maintenance in Earth. Moreover, in some cases, the traditional treatment schemes, most usually applied to abate the pollutant character of liquid effluents involving biological systems, may not be convenient due to their sensitivity to toxic compounds and to seasonal variations on the flow and composition of the effluent. Thus the development of suitable alternative technologies is an important challenge for chemical engineers.

In the last decades, Fenton's process showed interesting results for the depuration of a wide range of bio-refractory effluents (Bautista et al., 2008). In fact, this advanced oxidation process reveals several advantages to be implemented at an industrial scale: it can be applied at room conditions of pressure and temperature, deals with easy to 
handle reactants and does not require sophisticated equipment. However, this homogeneous system calls for the separation of the dissolved iron from the treated effluent which is generally accomplished by introducing an alkaline compound able to precipitate iron in the form of $\mathrm{Fe}(\mathrm{OH})_{3}$. This procedure leads to high amounts of iron sludge which entail subsequent management constituting one of the major drawbacks of this treatment technique. To overcome this shortcoming, several solid catalysts have been tested to check their catalytic activity to enhance hydrogen peroxide oxidant power over organic pollutants (Soon and Hameed, 2011). In our research group the composite $\mathrm{Fe}-\mathrm{Ce}-\mathrm{O} 70 / 30$ revealed promising results on the peroxidation of olive mill wastewaters (Martins et al., 2010). Due to the operating costs associated with the catalyst acquisition and replacement whenever its activity decreases significantly, it is interesting to search for natural materials able to catalyze Fenton's process and that can be less onerous.

Volcanic rock is an inexpensive solid rich in metals and easily available. In fact, Valdés et al. (2008) revealed that volcanic sand could be successfully applied as catalyst in catalytic ozonation of benzothiazole aqueous solution. Sepiolite is a very abundant hydrotalcite-like material usually characterized by high specific surface area and by its ability to adsorption. In fact, Rodríguez et al. (2010) verified that this was the best catalyst (iron supported on sepiolite) to degrade acid orange II by heterogeneous Fenton's process. Bremmer et al. (2006) developed a methodology involving the production of hydroxyl radicals by hydrogen peroxide decomposition through the direct oxidation of metallic iron (zero valent iron-ZVI). This way, the use of iron salts may be replaced by costless iron shavings, which are wastes from iron processing industries (Zhao et al., 2006; Kallel et al., 2009; Martins et al., 2012).

Thus, the aim of the present paper is to test low cost materials such as red volcanic rock, sepiolite and iron shavings (coming from Fe processing industries) without modification as catalysts, on the peroxidation of simulated and actual olive mill wastewaters (OMW). To grasp the main features of the process, the impact of the key operating parameters were analyzed using a synthetic solution before using an actual olive mill wastewater. Moreover, one of the ruling points for the industrial application of a heterogeneous process is the stability of the catalyst in continuous operation which is usually not found in literature and will be thus addressed.

\section{Materials and methods}

\subsection{Oxidation procedure}

Fenton's process was carried out in batch operation as described elsewhere (Martins et al., 2012); briefly, dark bottles with $60 \mathrm{~mL}$ of the synthetic wastewater, the catalyst and hydrogen peroxide (industrial grade, $50 \% \mathrm{w} / \mathrm{w}$ ) were stirred in an orbital shaker at $16 \mathrm{rpm}$ (Heidolph-Reax 20). The withdrawn samples were immediately alkalinized by introducing $\mathrm{NaOH}(\mathrm{pH} 8-9)$ to promote hydrogen peroxide decomposition so that this reactant did not interfere in the analytical techniques. However, the reaction was not stopped in a certain volume of the treated wastewater to allow determining the remaining $\mathrm{H}_{2} \mathrm{O}_{2}$ in solution as well as the amount of iron leached during the process.

To infer about the catalyst stability during several hours of utilization, a continuous laboratory scale fixed bed reactor with $9.5 \mathrm{~mm}$ of internal diameter and $14.5 \mathrm{~cm}$ height was used. The column was filled with $12.3 \mathrm{~g}$ of catalyst leading to a bed porosity of 0.77 . The effluent (mixed with hydrogen peroxide) was continuously fed $(1 \mathrm{~mL} / \mathrm{min})$ throughout a peristaltic pump (ISMATEC -Reglo). Samples of the treated effluent leaving the top of the column were periodically analyzed.
Commercially available red volcanic rock and sepiolite were used. Iron shavings (wastes from iron industry) were collected from a local iron processing plant. The catalysts were crushed before being used and particles with diameters within the range $250-500 \mu \mathrm{m}$ were used for the case of red volcanic rock and sepiolite. In what regards ZVI, the shavings were used as collected with diameters within the range 0.841-1.140 $\mathrm{mm}$.

\subsection{Analytical techniques}

COD (chemical oxygen demand) and BOD (biochemical oxygen demand) were determined according to the Standard Methods (1992) as described previously (Martins et al., 2012). For COD, the samples were digested in a WTW CR3000 thermoreactor, and the COD was directly read in a WTW MPM 3000 photometer, whereas in what regards BOD, the dissolved oxygen measurement was carried out in a WTW INOLAB 740 Stirrox apparatus. Total organic carbon (TOC) was attained using a Shimadzu TOC 5000. The phenolic content (TPh) was obtained throughout the Folin-Ciocalteau method (Folin and Ciocalteu, 1927; Silva et al., 2007), briefly, $20 \mu \mathrm{L}$ of the sample were diluted with $1.58 \mathrm{~mL}$ of deionized water, $100 \mu \mathrm{L}$ of the Folin-Ciocalteau reactant were introduced and the mixture was alkalinized by the addition of $300 \mu \mathrm{L}$ of a $\mathrm{Na}_{2} \mathrm{CO}_{3}$ saturated solution. After $2 \mathrm{~h}$ of reaction in the dark, the absorbance at $765 \mathrm{~nm}$ was determined in a T60 spectrophotometer (PG instruments). The wastewater eco-toxicity was analyzed by measuring its impact over Vibrio fischeri light production inhibition using a LUMIStox (Dr. Lange) as described before (Martins et al., $2010)$; thus the effective concentration able to restrain $20 \%\left(\mathrm{EC}_{20}\right)$ and $50 \%\left(\mathrm{EC}_{50}\right)$ of the bacteria population was attained.

pH was measured using a Crison micropH 2002 pH-meter and hydrogen peroxide concentration was obtained using Precision Laboratories Peroxide Test Strips.

The amount of metals present in the solid catalysts (after acid digestion) and the quantity of iron leached to the effluent after Fenton's reaction were determined by Atomic Absorption Spectrophotometry (FAAS-Perkin-Elmer 3000), while elemental analysis (Fisons Instruments EA 11081108 CHNS-O) was used to check for carbon in the solid catalysts surface.

The solids Brunauer-Emmet-Teller surface area (BET) was assessed using an accelerated surface area and porosimetry analyzer (ASAP 2000, Micromeritics). X-ray powder diffraction (XRD) analysis was performed using a Philips PW 3040/00 X'Pert analyzer.

The results reported are the average of at least duplicate determinations; the standard deviations are also represented. The difference between two replicate experiments was always lower than $1.5 \%$ and $4 \%$ for TOC and COD, respectively.

\subsection{Wastewater preparation and characterization}

In a first stage of the experimental work, a synthetic effluent encompassing six phenolic acids was prepared to mimic olive mill wastewater. The mixture was prepared using $100 \mathrm{mg} / \mathrm{L}$ of each of the following acids: trans-cinnamic, gallic, 4-hydroxybenzoic, 3,4dihydroxybenzoic, 3,4,5-trimethoxybenzoic and 3,4-dimethoxybenzoic acids. Table 1 shows the main characteristic this effluent.

After the optimization of Fenton's process using the simulated mixture, an actual olive mill effluent (OMW) collected from an olive oil production plant in Spain was also tested. Table 1 shows the main characteristics of OMW after the solids removal by filtration. 
Table 1

Synthetic and actual wastewater characterization.

\begin{tabular}{|c|c|c|c|c|c|c|}
\hline Effluent & TOC (ppm) & TPh (ppm) & $\operatorname{COD}\left(\mathrm{mg} \mathrm{O}_{2} / \mathrm{L}\right)$ & $\mathrm{BOD}_{5}\left(\mathrm{mg} \mathrm{O}_{2} / \mathrm{L}\right)$ & $\mathrm{EC}_{20}(\%)$ & $\mathrm{EC}_{50}(\%)$ \\
\hline Synthetic & $301.6 \pm 8.3$ & $358 \pm 30$ & $1055 \pm 15$ & $372 \pm 20$ & $10 \pm 2$ & $35.5 \pm 2$ \\
\hline Actual OMW & $1150 \pm 75$ & $332 \pm 36$ & $2065 \pm 48$ & $567 \pm 20$ & $0.08 \pm 2$ & $0.38 \pm 2$ \\
\hline
\end{tabular}

Table 2

Main characteristics of the catalysts used.

\begin{tabular}{llll}
\hline & $\begin{array}{l}\text { Red volcanic } \\
\text { rock }\end{array}$ & Sepiolite & $\begin{array}{l}\text { Iron shavings } \\
(\mathrm{ZVI})\end{array}$ \\
\hline $\begin{array}{l}\mathrm{S}_{\mathrm{BET}}\left(\mathrm{m}^{2} / \mathrm{g}\right) \\
\begin{array}{l}\text { Average pore diameter } \\
(\mu \mathrm{m})\end{array}\end{array}$ & $\begin{array}{l}3.49 \pm 0.02 \\
0.00158\end{array}$ & $\begin{array}{l}226.65 \pm 0.04 \\
0.00479\end{array}$ & $\begin{array}{l}1.14 \pm 0.04 \\
0.00443\end{array}$ \\
\hline
\end{tabular}

\section{Results and discussion}

\subsection{Caracterization of the catalysts}

In a first step, the low cost catalysts (red volcanic rock, sepiolite and ZVI) were characterized. Table 2 describes the materials textural characteristics involving the BET surface area $\left(S_{\mathrm{BET}}\right)$ and the average pore size determined by $\mathrm{N}_{2}$ adsorption-desorption at $77 \mathrm{~K}$. As an example, in Fig. 1a the isotherm attained for sepiolite is shown. Red volcanic rock and ZVI show very low specific surface area when compared with sepiolite. The solids reveal pore diameters within the range of $0.00158-0.00479 \mu \mathrm{m}$ which are typical of micro/mesoporous structures.

For the three catalysts in study the amount on metals $(\mathrm{Fe}, \mathrm{Cu}$, $\mathrm{Zn}, \mathrm{K}, \mathrm{Na}, \mathrm{Cr}, \mathrm{Mn}, \mathrm{Ca}$ and $\mathrm{Mg}$ ) was measured by atomic absorption (after previously acid digestion). The results revealed that ZVI is practically totally composed by Fe. Regarding sepiolite, the content in $\mathrm{Fe}$ is only of $2 \%$ and $\mathrm{Mg}$ is the most abundant metal (10\%). Relatively to red volcanic rock in terms of Fe the content is $6 \%$, being the major composition among measured between all the others compounds analyzed.

$\mathrm{X}$-ray diffraction analysis of red volcanic rock indicated the presence of hematite $\left(\mathrm{Fe}_{2} \mathrm{O}_{3}\right)$, pyroxenes (inosilicate minerals); quartz $\left(\mathrm{SiO}_{2}\right)$ and feldspars $\left(\mathrm{KAlSi}_{3} \mathrm{O}_{8}-\mathrm{NaAlSi}_{3} \mathrm{O}_{8}-\mathrm{AlSi}_{3} \mathrm{O}_{8}\right)$. In what concerns sepiolite, magnesium silicate hydroxide hydrate $\left(\mathrm{Mg}_{8}(\mathrm{OH})_{4} \mathrm{Si}_{12} \mathrm{O}_{30}\left(\mathrm{H}_{2} \mathrm{O}\right)_{12}\right)$ was found (Fig. 1b). Regarding ZVI, it was possible to conclude that it was a ferritic stainless steel.

\subsection{Screening of the catalysts}

Three low cost materials were selected to check their suitability to enhance hydrogen peroxide action over pollutants during Fenton's process, namely, iron shavings which are wastes from iron processing industry (ZVI), red volcanic rock and sepiolite. Since the aim is to minimize costs with the catalyst preparation and production, the solids were used as obtained without further modification.

The screening experiments were carried out in a batch vessel with a volume of $60 \mathrm{~mL}$ at room pressure and temperature using a hydrogen peroxide concentration of $35 \mathrm{mM}$ (this value corresponds to half stoichiometric value theoretically need to totally oxidize organic material present in the effluent (Eckenfelder, 1989)) and $\mathrm{pH} 3$ since this is usually the $\mathrm{pH}$ value reported as optimal for Fenton's peroxidation (Neyens and Baeyens, 2003). In the first tests, the catalyst load was changed within the range of 1-10 $\mathrm{g} / \mathrm{L}$; nevertheless, no significant differences between the three materials efficiencies regarding TPh, TOC and COD removal were detected after 120 min of reaction (17-20\%). However, when the treatment was performed with $40 \mathrm{~g} / \mathrm{L}$ of catalytic material, the

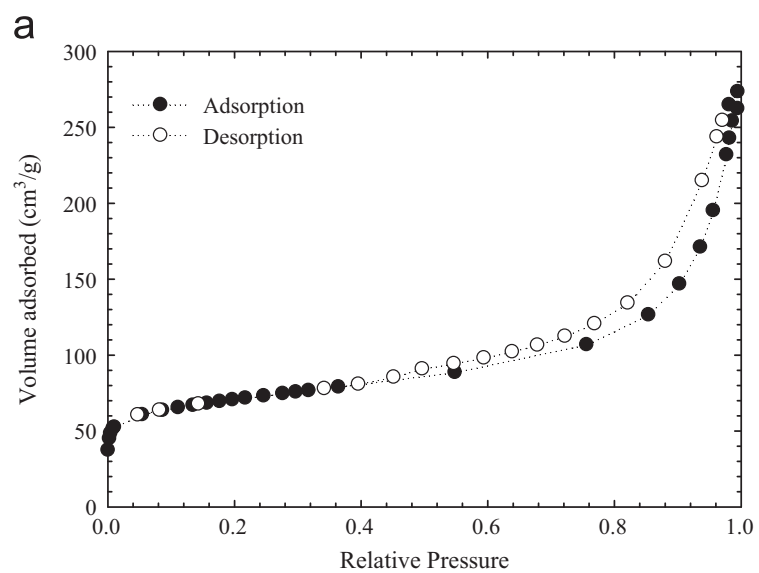

b

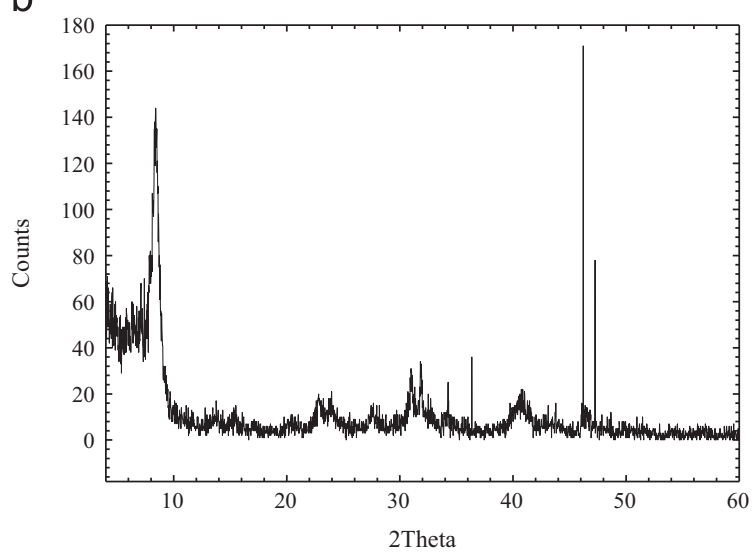

Fig. 1. (a) Nitrogen adsorption/desorption isotherm and (b) XRD difractogram for sepiolite.

results obtained reveal that $\mathrm{ZVI}$ is the most promising catalyst for the abatement of pollutants present in the simulated effluent by Fenton's process (Fig. 2). From these results, one can observe a high TPh removal, after $120 \mathrm{~min}$ of reaction, whichever the catalyst used with the lowest degradation (65\%) attained by sepiolite and the highest (87\%) reached by ZVI. In fact, phenolic compounds are usually prone to oxidation due to the presence on their structure of electron donating groups such as hydroxyl $(\mathrm{OH})$ and methoxy $\left(\mathrm{CH}_{3} \mathrm{O}\right)$ that promote an easy electrophilic attack to the aromatic ring. Nonetheless, when parameters such as COD and TOC are considered, strong differences are found for the catalytic systems in study. Thus, ZVI shows the main COD and TOC depletion reaching about $50 \%$ and $60 \%$, respectively. It is well known that hydrogen peroxide action is highly enhanced by the presence of iron (Neyens and Baeyens, 2003), and according to the catalysts characterization data, ZVI is almost totally composed by this metal. Besides, in agreement with Bremmer et al. (2006) the use of ZVI enhances the ferric iron reduction into ferrous ions over the metallic surface. Furthermore, no hydrogen peroxide was found after 120 min which means that all the oxidant initially loaded was consumed during the treatment. 


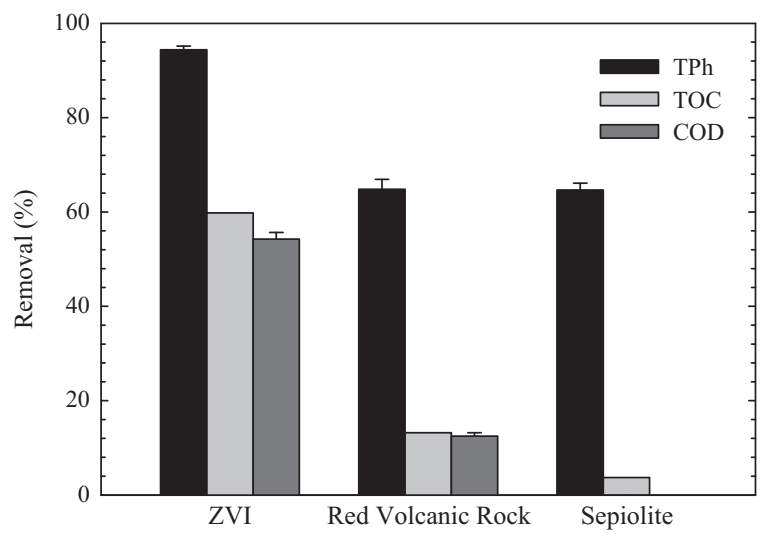

Fig. 2. TPh, TOC and COD removal after $120 \mathrm{~min}$ by Fenton's process over the different low cost catalysts (catalyst load $=40 \mathrm{~g} / \mathrm{L}$ ).

When red volcanic rock was tested, barely $13 \%$ of COD and TOC removal was attained. In fact, this material showed a low content in iron (6\%) which may explain its low efficiency over Fenton's oxidation of organic matter.

The lowest COD and TOC depletion was attained when sepiolite was used (below $4 \%$ which is even within the typical analytical error for those parameters determination). The small efficiency of this clay mineral to enhance hydrogen peroxide action over pollutants is also evident when the amount of $\mathrm{H}_{2} \mathrm{O}_{2}$ remaining after 120 min of reaction was determined; indeed almost all the initial loaded oxidant was detected at the end of the process strengthening that sepiolite by itself is not a suitable catalyst for this treatment technology. These results are contradictory to those found in literature (Rodríguez et al., 2010); however, it should be pointed out that in those cases sepiolite was used as support of the active metal. It seems thus that this mineral is more suitable to be used as a support than as catalyst by itself.

It should be still referred that $\mathrm{pH}$ increased in all catalytic systems (reaching 5.9 when ZVI was applied) probably due to the degradation of the initial phenolic acids.

Bearing in mind the interesting results attained when iron shavings were applied as catalysts in Fenton's process, the following experiments were carried out using this catalytic material.

\subsection{Fenton's process over ZVI}

\subsubsection{Effect of catalyst concentration}

In order to evaluate the effect of ZVI load in Fenton-process efficiency, experiments were carried out where the catalyst concentration was varied within the range between $10 \mathrm{~g} / \mathrm{L}$ and $60 \mathrm{~g} / \mathrm{L}$ using a $\left[\mathrm{H}_{2} \mathrm{O}_{2}\right]$ of $35 \mathrm{mM}$ and with an initial $\mathrm{pH}$ of 3 . The results obtained after 120 min of reaction regarding TPh, COD and TOC depletion are depicted in Fig. 3. In terms of total phenolic content, removals above $70 \%$ were always possible to achieve whichever the ZVI load; besides, the maximum of TPh degradation (94.4\%) was attained for the ZVI concentration of $40 \mathrm{~g} / \mathrm{L}$.

Throughout the analysis of these results one can verify that both COD and TOC removal increased with the rise of ZVI concentration, and, once more, the highest efficiency was attained when $40 \mathrm{~g} / \mathrm{L}$ of ZVI were used. In this case, a maximum removal of $50 \%$ and $60 \%$ was reached for COD and TOC, respectively. However, a slight decrease on COD degradation was detected when $60 \mathrm{~g} / \mathrm{L}$ of ZVI were tested; in fact, it is well known that when the catalyst is in excess, iron species are able to scavenge hydroxyl radicals reducing, this way, the system oxidation efficiency (Ramirez et al., 2007).

It should be pointed out that for ZVI concentrations above $40 \mathrm{~g} / \mathrm{L}$ it was verified an increase on the solution $\mathrm{pH}$ to 6 , most likely due to

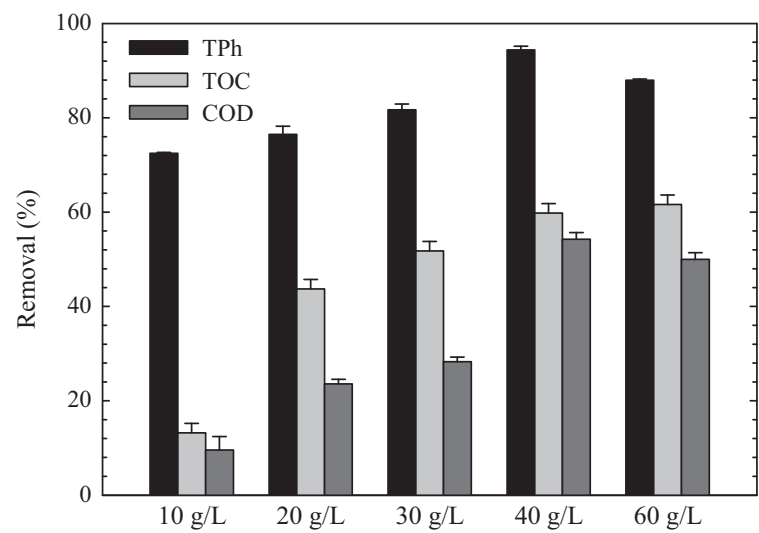

Fig. 3. Effect of ZVI load over Fenton's efficiency regarding TPh, TOC and COD removal.

the high abatement on the wastewater phenolic acids content. In terms of residual hydrogen peroxide concentration after the end of reaction, only for ZVI loads within the range between $10 \mathrm{~g} / \mathrm{L}$ and $30 \mathrm{~g} / \mathrm{L}$ it was still possible to detect traces of $\mathrm{H}_{2} \mathrm{O}_{2}$, whereas when $\mathrm{ZVI}>30 \mathrm{~g} / \mathrm{L}$, no hydrogen peroxide was found after $120 \mathrm{~min}$ of reaction denoting that the use of ZVI concentrations below $40 \mathrm{~g} / \mathrm{L}$ do not lead to an efficient use of all the oxidant introduced in the reactor. With these results, it becomes evident that a ZVI concentration of $40 \mathrm{~g} / \mathrm{L}$ should be applied to maximize Fenton's process efficiency. Thus, this value was selected to carry on the following experiments.

\subsubsection{Effect of $\mathrm{H}_{2} \mathrm{O}_{2}$ concentration}

The hydrogen peroxide concentration is another important parameter in the Fenton process since $\mathrm{H}_{2} \mathrm{O}_{2}$ is the oxidant responsible for the organic matter degradation, being the source of highly reactive hydroxyl radicals in the presence of iron at acidic pH (Neyens and Baeyens, 2003).

In order to determine the optimum amount of hydrogen peroxide to be used in the phenolic mixture over ZVI, experiments were carried out varying $\left[\mathrm{H}_{2} \mathrm{O}_{2}\right]$ within the range between 8.75 and $138 \mathrm{mM}$ corresponding to $1 / 8$ and 2 times the stoichiometric amount theoretically required to totally degrade the initial COD of the mixture. The tests were performed using a ZVI concentration fixed in the value of $40 \mathrm{~g} / \mathrm{L}$ and with initial $\mathrm{pH} 3$ : the results attained after $120 \mathrm{~min}$ are shown in Fig. 4a.

The analysis of these results (Fig. 4a), allow to conclude that $\mathrm{TPh}, \mathrm{TOC}$ and COD maximum removal occurs when an $\mathrm{H}_{2} \mathrm{O}_{2}$ concentration of $35 \mathrm{mM}$ was utilized. The total phenolic content degradation increases with the amount of $\mathrm{H}_{2} \mathrm{O}_{2}$ used, reaching a maximum of efficiency of $94 \%$ for a $\mathrm{H}_{2} \mathrm{O}_{2}$ load of $35 \mathrm{mM}$. Nevertheless, for higher $\left[\mathrm{H}_{2} \mathrm{O}_{2}\right]$ TPh depletion decreases, for example, for $\left[\mathrm{H}_{2} \mathrm{O}_{2}\right]=69 \mathrm{mM}$ TPh abatement is below $90 \%$.

Similar results were attained regarding COD and TOC; in fact, no TOC removal was possible for $\mathrm{H}_{2} \mathrm{O}_{2}$ amounts superior to $35 \mathrm{mM}$, which means that total mineralization was inhibited. Accordingly, when compared with the maximum COD removal (for $35 \mathrm{mM}$ of hydrogen peroxide), COD depletion decreases about $10 \%$ for $\left[\mathrm{H}_{2} \mathrm{O}_{2}\right]>35 \mathrm{mM}$. This behavior is due to the well known radical scavenger effect (Eq. (1)) when excessive $\mathrm{H}_{2} \mathrm{O}_{2}$ loads are used (Martins et al., 2010; Kallel et al., 2009).

$\mathrm{HO}^{\bullet}+\mathrm{H}_{2} \mathrm{O}_{2} \rightarrow \mathrm{H}_{2} \mathrm{O}+\mathrm{HO}_{2}$.

In all experiments the final solution $\mathrm{pH}$ after $120 \mathrm{~min}$ of Fenton's peroxidation increased from 3 to around 6. This was most likely due to the degradation of the initial phenolic acids; moreover, according to Deng and Englehardt (2008), Fenton-ZVI systems tend to neutral $\mathrm{pH}$ due to the consumption of $\mathrm{H}^{+}$by the 
a

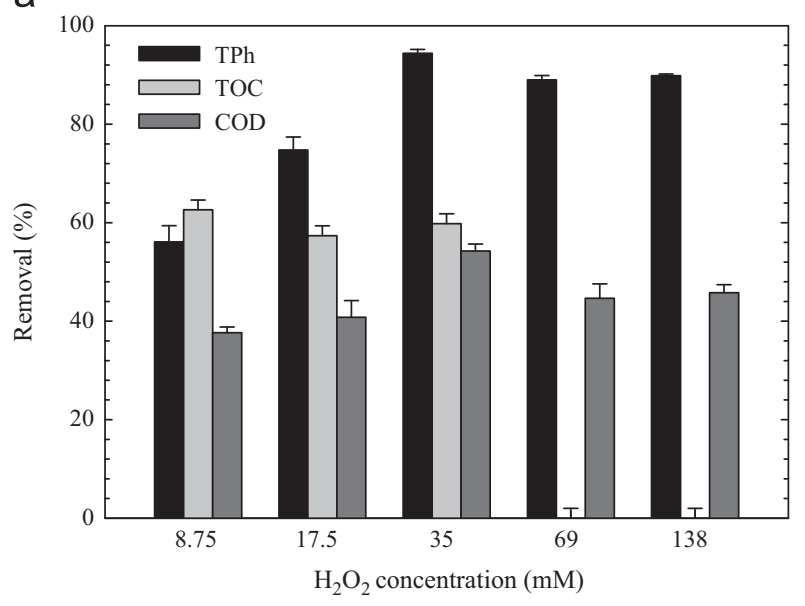

b

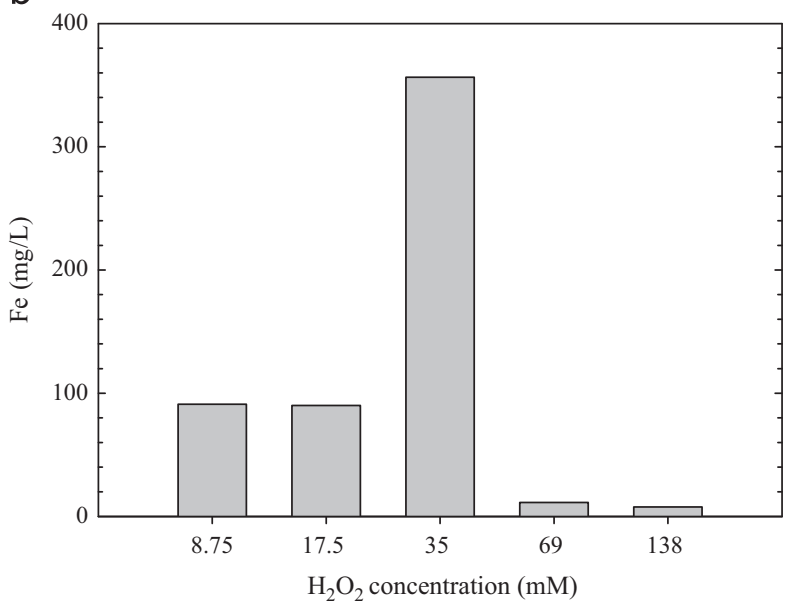

Fig. 4. Effect of hydrogen peroxide over (a) TPh, TOC and COD removal and (b) iron leaching after $120 \mathrm{~min}$ of Fenton's peroxidation.

zero valent iron. In what concerns the residual hydrogen peroxide after the reaction, all $\mathrm{H}_{2} \mathrm{O}_{2}$ was consumed when initial concentrations below or equal to $35 \mathrm{mM}$ were applied. Contrarily, for higher oxidant loads, traces of $\mathrm{H}_{2} \mathrm{O}_{2}$ were still possible to detect after $120 \mathrm{~min}$, meaning that this reactant was not totally used during the process.

As it can be observed in Fig. 4b, a high amount of iron was leached for the solution when a $\left[\mathrm{H}_{2} \mathrm{O}_{2}\right]=35 \mathrm{mM}$ was used; below this concentration the range of Fe leached was about $90 \mathrm{mg} / \mathrm{L}$ whereas above only $10 \mathrm{mg} / \mathrm{L}$ were detected. This variation should be related with the different kind of by-products formed under these diverse operating conditions which may lead to dissimilar leaching behaviors.

\subsubsection{Effect of $p H$}

Initial $\mathrm{pH}$ of the solution is an important parameter in the Fenton reaction once literature refers that in the presence of acidic conditions the corrosion of the surface of metallic iron (Eq. (2)) may occur leading to the formation of ferrous iron (Kallel et al., 2009).

$\mathrm{Fe}^{0}+2 \mathrm{H}^{+} \rightarrow \mathrm{Fe}^{2+}+\mathrm{H}_{2}$

In order to infer the impact of $\mathrm{pH}$ over Fenton's process with iron shavings, in this section tests varying the initial $\mathrm{pH}$ of reaction medium from 2 to 7 were conducted with ZVI and $\mathrm{H}_{2} \mathrm{O}_{2}$

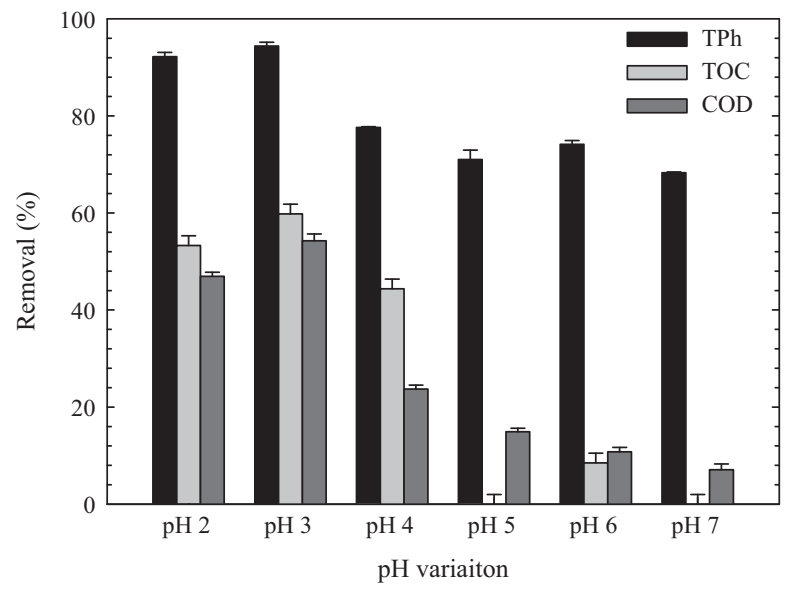

Fig. 5. Effect of initial pH over Fenton's efficiency regarding TPh, TOC and COD final removal (120 min).

concentrations fixed in $40 \mathrm{~g} / \mathrm{L}$ and $35 \mathrm{mM}$, respectively (the best conditions obtained in the previous studies).

Fig. 5 shows the results in terms of TPh, TOC and COD removal for all the experiments. As it can be observed, the highest TPh abatement was attained for very acidic conditions ( $\mathrm{pH} 2$ and 3) reaching $93 \%$ and $94 \%$ of TPh degradation, respectively. However, only a slight decrease in TPh depletion efficiency was observed when the initial $\mathrm{pH}$ value was within the range 4-7 (68-78\%).

Relative to TOC and COD removal, one can observe an increase on the treatment performance when the initial $\mathrm{pH}$ rose from 2 to 3 . For this pH both TOC (60\%) and COD (54\%) reached the highest degradation value. Furthermore, for higher $\mathrm{pH}$ values, TOC and COD depletion decreases which is in accordance with literature where $\mathrm{pH} 3$ is referred as optimum for Fenton's process (Neyens and Baeyens, 2003). In fact, for alkaline conditions, hydrogen peroxide self-decomposition into oxygen and water is enhanced, reducing, this way, the amount of oxidant available for the treatment. Besides, for high $\mathrm{pH}$ values, formation of ferric complexes is reported leading to catalysts deactivation decreasing, thus, the amount of hydroxyl radicals production (Kallel et al., 2009; Chu et al., 2012).

When the amount of Fe leached for the solution was analyzed for the different $\mathrm{pH}$ tests, a high amount of Fe was detected when pH 2 was applied $(4700 \mathrm{mg} / \mathrm{L})$, a value much higher than the one recorded for $\mathrm{pH} 3$. As expected, the iron content in the liquid phase lowered with the increase of $\mathrm{pH}$ : for $\mathrm{pH} 428.4 \mathrm{mg} / \mathrm{L}$ and for the subsequent alkaline $\mathrm{pH}$ the amount of Fe leached was inferior to $5 \mathrm{mg} / \mathrm{L}$.

It is worthy to focus that when the initial $\mathrm{pH}$ was 2 and 3, the final value determined after 120 min of Fenton's peroxidation was around 6 which is related with the degradation of the initial phenolic compounds. Moreover, ZVI is known by the ability of consuming $\mathrm{H}^{+}$which may also explain this $\mathrm{pH}$ increase.

\subsubsection{Effect of the presence of radical scavengers}

There is some discussion in literature around which are the oxidant responsible by Fenton's process over ZVI efficiency (hydroxyl radicals or $\mathrm{Fe}(\mathrm{IV})$ ); furthermore, there is no consensus whether these moieties act in the liquid bulk or as surface-bounded species (Xu and Wang, 2011). To infer about the mechanism responsible by the degradation of the synthetic phenolic effluent, experiments were carried out $\left(40 \mathrm{~g} / \mathrm{L} \mathrm{ZVI}, 35 \mathrm{mM} \mathrm{H}_{2} \mathrm{O}_{2}\right.$ and $\mathrm{pH} 3$ ) in the presence of radical scavenger compounds. Therefore it was added $n$-butanol $(350 \mathrm{mM})$ with the aim of scavenging the hydroxyl radicals produced through both free pathway and ZVI surface 


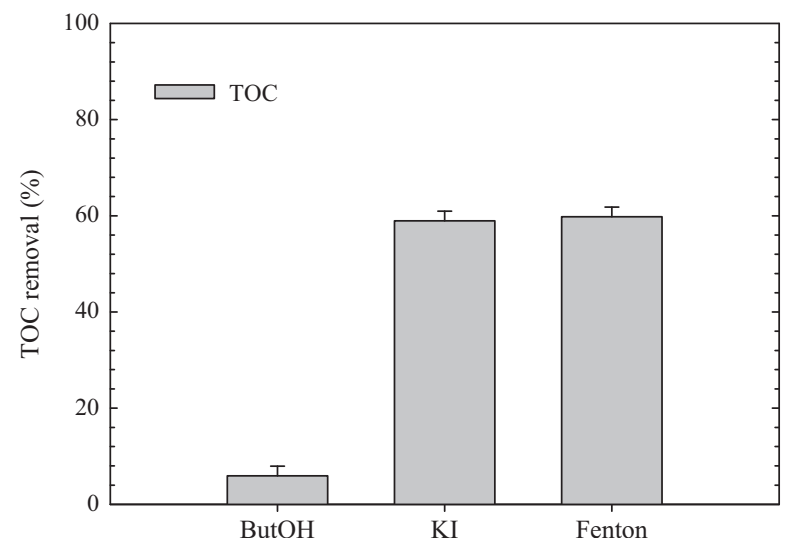

Fig. 6. Effect of the presence of radical scavengers over TOC degradation by Fenton's peroxidation.

bounded (Xu and Wang, 2011). Moreover, another test was carried out where potassium iodide was added $(7.0 \mathrm{mM})$ with the purpose to scavenge only the hydroxyl radical produced at the surface of the ZVI (Xu and Wang, 2011).

Through the observation of the data shown in Fig. 6, it can be concluded that a strong decrease in TOC removal was detected when $n$-butanol was used (6\%) when compared with the degradation attained in the case where no scavenger was used (60\%). These results reveal the strong role that hydroxyl radicals play in this process, being the main oxidant species present. Even so, in the presence of $n$-butanol still $6 \%$ of mineralization occurs which means that other moieties may be able to oxidize organic matter in a much lower extension though. When potassium iodide was added, TOC removal (58.9\%) was practically the same that the one attained in the absence of this reactant, revealing that hydroxyl radicals in the liquid bulk are more relevant rather than attached in the ZVI surface.

\subsubsection{Optimal conditions}

Taking into consideration the interesting results previously reached, it was possible to consider between the three solids tested that the use of iron shavings as catalyst in Fenton's process leads to the most promising removal of organic matter present in the synthetic phenolic effluent. Bearing in mind the ZVI it was possible to determine that the optimum catalyst and $\mathrm{H}_{2} \mathrm{O}_{2}$ load was $40 \mathrm{~g} / \mathrm{L}$ and $35 \mathrm{mM}$, respectively, besides, an initial $\mathrm{pH}$ of 3 .

Under these operating conditions, the temporal evolution of synthetic effluent treatment was now analyzed. Fig. 7a shows TPh, COD and TOC removal trend during $120 \mathrm{~min}$ of Fenton's peroxidation.

One can observe that for all the parameters, a strong depletion occurs within the first hour of reaction. After $60 \mathrm{~min} 90 \%$ of TPh was degraded and after this reaction time, the removal rate is much slower leading to a final efficiency of $94.4 \%$ (after $120 \mathrm{~min}$ ). Similar behavior is detected for TOC and COD. These results are in accordance with the evolution of residual hydrogen peroxide concentration; in fact after $60 \mathrm{~min}$, no $\mathrm{H}_{2} \mathrm{O}_{2}$ was detected explaining the degradation rate slowing down.

An important aspect when using a heterogeneous catalyst concerns with the possibility of some of the dissolved carbon being adsorbed in the solid surface rather than be oxidized. Besides, this may lead to the catalyst deactivation due to active sites blockage. Therefore, the catalyst at the end of reaction was analyzed in terms of carbon adsorption and no carbon adsorbed in the solid was detected after 120 min of reaction, evidencing that a

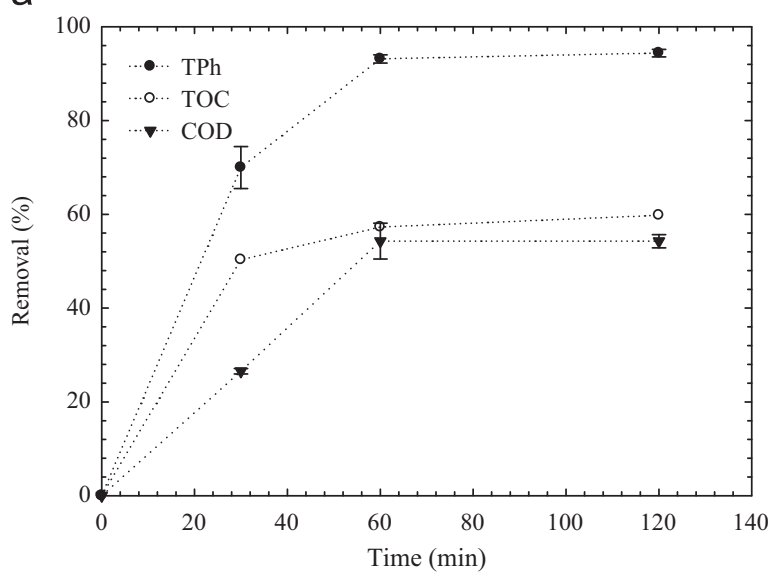

b

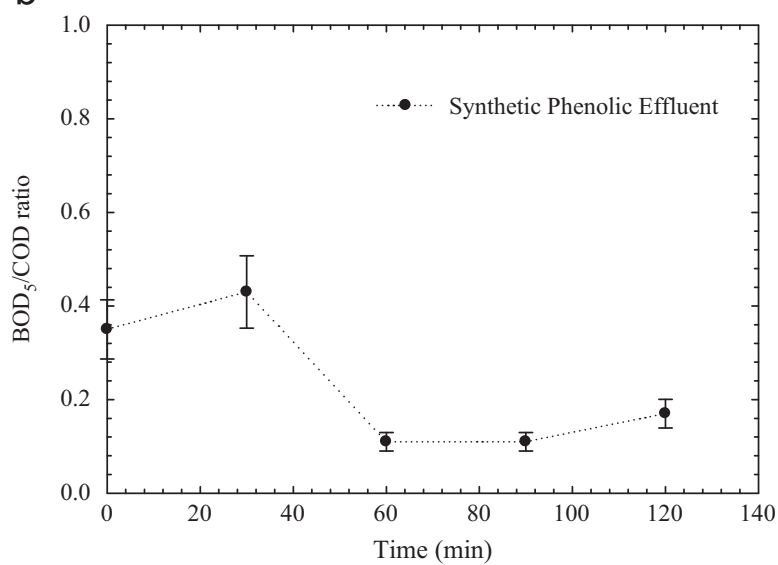

C

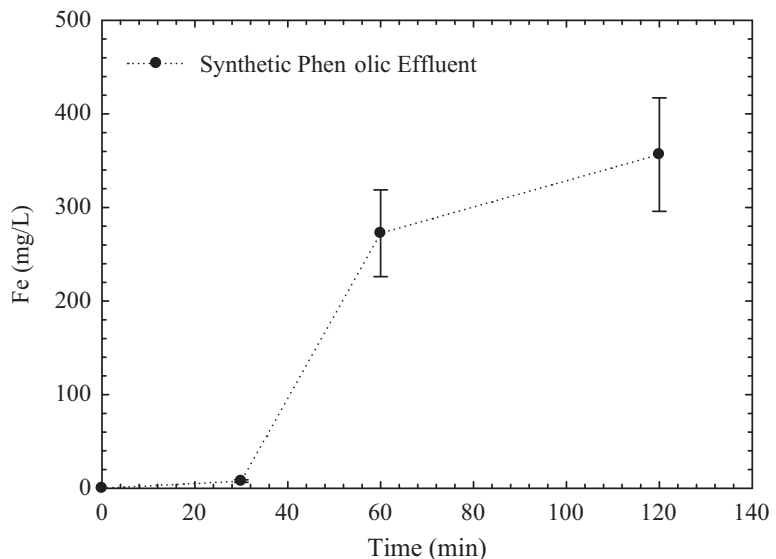

Fig. 7. Temporal trend of (a) TPh, TOC and COD removal, (b) BOD5/COD ration and (c) iron leaching during Fenton's peroxidation of the simulated phenolic effluent under the optimal operating conditions $\left(40 \mathrm{~g} / \mathrm{L}\right.$ of $\mathrm{ZVI},\left[\mathrm{H}_{2} \mathrm{O}_{2}\right]=35 \mathrm{mM}$ and $\mathrm{pH} 3$ ).

the pollutants abatement was due to chemical oxidation through Fenton's reaction.

A relevant parameter that has also to be taken into account is the biodegradability of the effluent during the chemical treatment. In fact, in some situations it may be interesting to use an advanced oxidation process until being reached a depurated wastewater amenable to be further bio-processed. Thus, $\mathrm{BOD}_{5} / \mathrm{COD}$ is usually followed up (Fig. 7b). As it can be observed the initial solution presents a $\mathrm{BOD}_{5} / \mathrm{COD}$ ratio of about 0.35 and during the first 30 min of Fenton's reaction this value raises to 0.43 , probably due 
to the high depletion of the bio-refractory and toxic parent phenolic compounds. In fact, usually for an effluent to be considered totally biodegradable a ratio superior to 0.4 should be attained (Esplugas et al., 2004). However, for longer treatment times, a decrease on the value of $\mathrm{BOD}_{5} / \mathrm{COD}$ is observed, most likely due to the accumulation of bio-refractory by-products. Besides, as it can be confirmed in Fig. 7c, that represents the amount of iron leached to the liquid during Fenton's process, after $60 \mathrm{~min}$ of reaction a high amount of $\mathrm{Fe}$ (above $300 \mathrm{mg} / \mathrm{L}$ ) is detected in the treated wastewater which also may be highly inhibitory to microorganisms.

Another important parameter is the eco-toxicity inherent to the synthetic effluent in the end of Fenton's reaction, since phenolic compounds are well known by their negative impact over ecosystems. Therefore, $\mathrm{EC}_{50}$ (wastewater dilution able to restrain light production of $50 \%$ of Vibrio Fischeri bacteria population) was determined along Fenton's process. The high toxic character of the initial synthetic effluent was confirmed being determined that a solution involving only $35.5 \%$ of the wastewater was able to inhibit $50 \%$ of the microorganisms. A high decrease on the ecological impact of the polluted stream was possible by treating it with Fenton's process over ZVI since after $120 \mathrm{~min}$ $\mathrm{EC}_{50}$ was out of the range of the apparatus meaning that even the undiluted treated effluent was not able to restrain light production of $50 \%$ of the bacteria.

After application of Fenton's peroxidation in the synthetic effluent to grasp the impact of the main parameters ruling this treatment efficiency $\left(\mathrm{ZVI},\left[\mathrm{H}_{2} \mathrm{O}_{2}\right]\right.$ and $\left.\mathrm{pH}\right)$, the optimized operating conditions were used in an actual olive mill wastewater.

\subsection{Actual OMW treatment}

Fenton's process under the optimal operating conditions described before ( $\mathrm{pH} \mathrm{3,} \mathrm{ZVI} \mathrm{and} \mathrm{H}_{2} \mathrm{O}_{2}$ concentration of $40 \mathrm{~g} / \mathrm{L}$ and $35 \mathrm{mM}$, respectively) was applied to an actual olive mill wastewater. Fig. 8a shows TPh, COD and TOC temporal trends during treatment.

As it is possible to confirm with these data, the results attained when Fenton's process over ZVI was used to treat a real olive mill wastewater were very similar to those before with the phenolic synthetic solution. In fact, a high depletion in terms of TPh in the first 30 min of reaction was still observed being reached a final removal above $90 \%$. In what regards TOC and COD, one can observe that the maximum depletion (60\% and $30 \%$, respectively) is attained after $30 \mathrm{~min}$ of reaction and a plateau with negligible further degradation is reached afterwards. These efficiencies are very similar to those accomplished for the synthetic effluent. Even so, it is evident that Fenton reaction was faster in the case of the actual effluent probably due to the higher organic charge which increased the initial reaction rate. Besides, according to Fig. 8b, the amount of iron leached to the solution is higher for the real olive mill wastewater for the first $30 \mathrm{~min}$ of reaction (caused by the presence of different compounds in solution that will promote a different iron leaching behavior), since, as referred before, free hydroxyl radicals are likely to be the main oxidant species in this system. In this context, the higher the amount of Fe in solution, most probably more hydroxyl radicals are prone to be produced promoting this way organic matter oxidation.

Relatively to $\mathrm{pH}$ evolution along time, it was verified that the olive mill wastewater $\mathrm{pH}$ increased to 4 after 30 min reaching a final value of 6 until the final of the reaction. In terms of residual $\mathrm{H}_{2} \mathrm{O}_{2}$, this oxidant was totally consumed after 30 min of reaction.

Once more, the possibility of some carbon being adsorbed in the catalyst surface was checked and no $\mathrm{C}$ was found in the recovered solid confirming that the degradation of organic matter was due to chemical oxidation through Fenton-process.
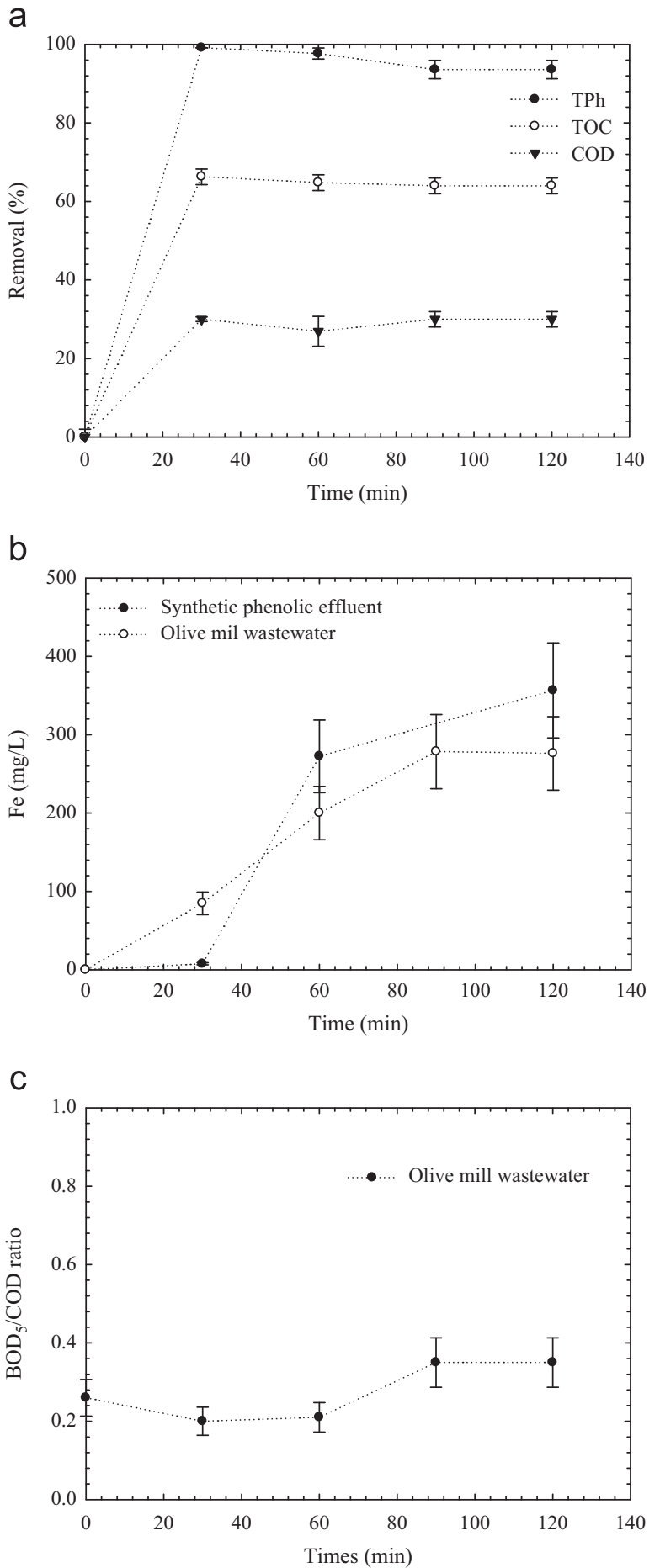

Fig. 8. Temporal trend of (a) TPh, TOC and COD removal, (b) iron leaching and (c) BOD5/COD during Fenton's peroxidation of the actual olive mill wastewater under the optimal operating conditions ( $40 \mathrm{~g} / \mathrm{L}$ of $\mathrm{ZVI},\left[\mathrm{H}_{2} \mathrm{O}_{2}\right]=35 \mathrm{mM}$ and $\mathrm{pH} 3$ ).

The initial olive mill wastewater, without any treatment, shows a low $\mathrm{BOD}_{5} / \mathrm{COD}$ ratio of 0.26 . In Fig. $8 \mathrm{c}$ are represented the results obtained in terms of $\mathrm{BOD}_{5} / \mathrm{COD}$ along Fenton's peroxidation. It can be verified that $\mathrm{BOD}_{5} / \mathrm{COD}$ ratio increase over time, in fact biodegradability varied between 0.20 and 0.35 from the $30 \mathrm{~min}$ reaction and attained the value of 0.35 in the final time reaction (120 min).

Relative to eco-toxicity of the olive mill wastewater before treatment, its high possible impact over the ecosystems if directly discharged to the natural water courses was observed, since a 
concentration of only $0.38 \%$ of OMW led to the inhibition of $50 \%$ $\left(\mathrm{EC}_{50}\right)$ of the marine bacteria. After treatment through Fenton's reaction a decrease on eco-toxicity was attained, with an increase in $\mathrm{EC}_{50}$ to $9.97 \%$.

\subsection{Stability of ZVI under continuous operation}

In this section the stability of iron shavings when applied as catalyst in a fixed bed reactor is evaluated. Therefore, experiments in continuous mode were carried out using the optimum operating conditions $\left(\left[\mathrm{H}_{2} \mathrm{O}_{2}\right]=35 \mathrm{mM}\right.$ and $\left.\mathrm{pH}=3\right)$ previously determined in batch tests. In these runs both the synthetic and actual effluents were applied and samples collected over time in terms of their evolution profiles of TPh, TOC and COD removal were analyzed.

Primarily, the synthetic effluent was treated in the continuous column in order to evaluate the iron shavings stability when submitted for long period's reaction. It is possible to verify in Fig. 9, TPh, TOC and COD removal profiles during $168 \mathrm{~h}$ operation using a flowrate of $1 \mathrm{~mL} / \mathrm{min}$ which leads to a residence time of $11.5 \mathrm{~min}$. All the samples periodically withdrawn at the end of the column had a final $\mathrm{pH}$ of 6 and no residual $\mathrm{H}_{2} \mathrm{O}_{2}$ was detected in the solution, which means that the $\mathrm{H}_{2} \mathrm{O}_{2}$ loaded was totally consumed. The residence time was selected bearing in mind the results attained at batch conditions. In fact, TOC, TPh and COD removal reach a plateau for reaction times below 20 min. Furthermore, iron leaching is low until that time.

In what concerns the phenolic content present in the effluent, as referred previously, it is very susceptible to oxidation and in Fig. 9 it can be observed that in the first 20 min a maximum TPh removal of $88.3 \%$ was obtained which is near the value in batch conditions. However, in the following minutes until the end of the column's operation a slight decrease in the phenolic content removal was detected always remaining above $70 \%$. On the order hand, for the first $20 \mathrm{~min}$ reaction, one can also observe a maximum TOC and COD removal ( $84.8 \%$ and $62.8 \%$, respectively) that decreases in the subsequent instants to values varying between $40 \%$ and $50 \%$ of removal. After $168 \mathrm{~h}$ of operation, it was still possible to reach removals in terms of TPh, TOC and COD of $73 \%, 39 \%$ and $44 \%$, respectively.

A concentration of leached iron of $223 \mathrm{mg} / \mathrm{L}$ (in the range of the batch reaction $7.6-356.5 \mathrm{mg} \mathrm{Fe} / \mathrm{L}$ ) was detected corresponding to the loss of about $2 \mathrm{~g}$ after $168 \mathrm{~h}$, barely $16 \%$ of the initially loaded iron shavings. Still, this value is above the legal limit for discharge to the natural water courses which means that a refining treatment able to remove this metal from solution such as alkalinization or the application of ion exchange resins would be required. However, this does not jeopardize the interest of using iron shavings as an alternative to the classic iron salts generally applied as Fenton's catalysts once this material is a waste from iron processing industry and, this way, wastewater treatment may be integrated with waste management at a lower cost.

After the satisfactory results attained with the simulated effluent, Fenton's reaction in the fixed bed reactor was applied to the actual olive mill wastewater. Thus, a $\left[\mathrm{H}_{2} \mathrm{O}_{2}\right]=35 \mathrm{mM}$ was used and $\mathrm{pH}$ was corrected to 3 . However, during the experiment, it was verified the precipitation of solids that led to the column clogging. This imposed that the operation ended after $4 \mathrm{~h}$ since the flowrate was reduced to $0.29 \mathrm{~mL} / \mathrm{min}$ (initially it was set in $1 \mathrm{~mL} / \mathrm{min}$ ). All the samples periodically collected for further analysis had a final $\mathrm{pH}$ of 6 and no residual $\mathrm{H}_{2} \mathrm{O}_{2}$ was detected.

In Fig. 10a it can be observed the TPh removal along $4 \mathrm{~h}$ of reaction comparing the results assessed with the synthetic and actual effluent. In both cases, the phenolic content was successfully removed with similar degradation efficiency. As expected, the phenolic content removal was slightly superior for the synthetic effluent due to the major composition complexity present in the

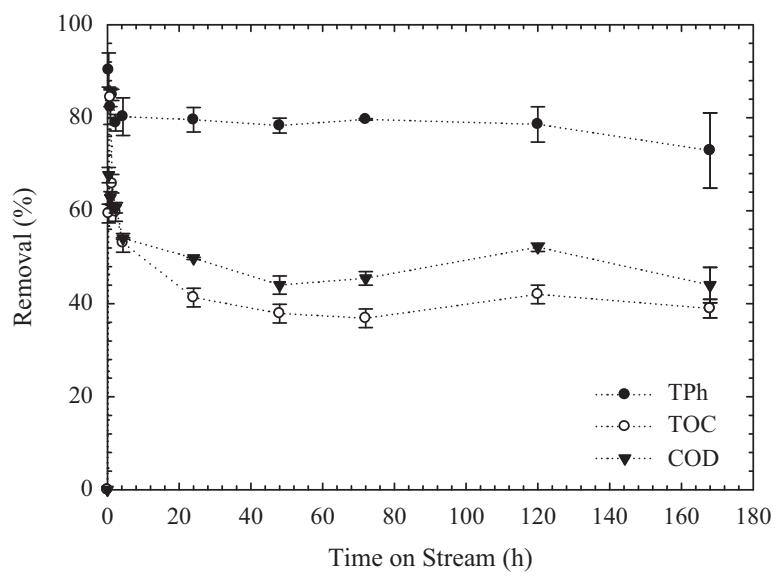

Fig. 9. Behavior of the continuous fixed bed reactor regarding $\mathrm{TPh}, \mathrm{TOC}$ and $\mathrm{COD}$ removal of the simulated effluent.

real olive mill wastewater. Regarding the maximum TPh for the actual wastewater this was attained after 23 min of reaction (85\%) followed by a steady decrease through time reaching a value still above $60 \%$ at the end of the column operation (254 min).

Regarding to TOC removal, the profile observed for the two effluents is shown in Fig. 10b, and once more the profiles over time are very similar. The maximum removal was about $79 \%$ after 23 min following by a decrease which led to 53\% after $254 \mathrm{~min}$ of reaction.

On the other hand, in what concerns the COD removal for the two effluents, it is possible to observe a substantial difference between the olive mill wastewater and the synthetic phenolic effluent (Fig. 10c). For the OWM the maximum COD removal (33.3\%) is reached after 23 min of operation of the column, which is a value $30 \%$ lower than the one attained for the synthetic mixture. This is most likely due to the higher complexity of OMW when compared with the synthetic effluent.

Similarly to what occurred with the synthetic effluent, for the OMW a drop in the COD removal was detected, being steeper after 167 min of operation of column caused by the column clogging by the solids leading to a final COD removal of $22 \%$. These results show the need of an efficient coagulation/flocculation system before the chemical oxidation process to minimize the possibility of solids precipitation during this stage.

\section{Conclusions}

With the aim of evaluating low cost catalysts materials for the application in Fenton's peroxidation, three heterogeneous catalysts (sepiolite, red volcanic rock and iron shavings) were evaluated in the treatment of a phenolic bio-refractory effluent. It was possible to determine that the most promising for the Fenton's reaction was iron shavings (ZVI) which has also the advantage of being a waste of iron industry and not needing any modification before being applied to Fenton's peroxidation. The impact of the several operating conditions ruling this process efficiency (ZVI load, hydrogen peroxide concentration and initial $\mathrm{pH}$ ) was analyzed being concluded that the best conditions involved $40 \mathrm{~g} / \mathrm{L}$ of $\mathrm{ZVI}$, $\left[\mathrm{H}_{2} \mathrm{O}_{2}\right]=35 \mathrm{mM}$ and $\mathrm{pH}=3$. These values led to interesting results in terms of TPh, COD and TOC removal $(94.4 \%, 54.2 \%$ and $59.8 \%$, respectively) once applied to treat a synthetic phenolic effluent. With these optimized operating conditions promising degradations were also attained when Fenton over ZVI was used with an actual olive mill wastewater, being reached too an increase on biodegradability and a decrease of the eco-toxicity. 
a

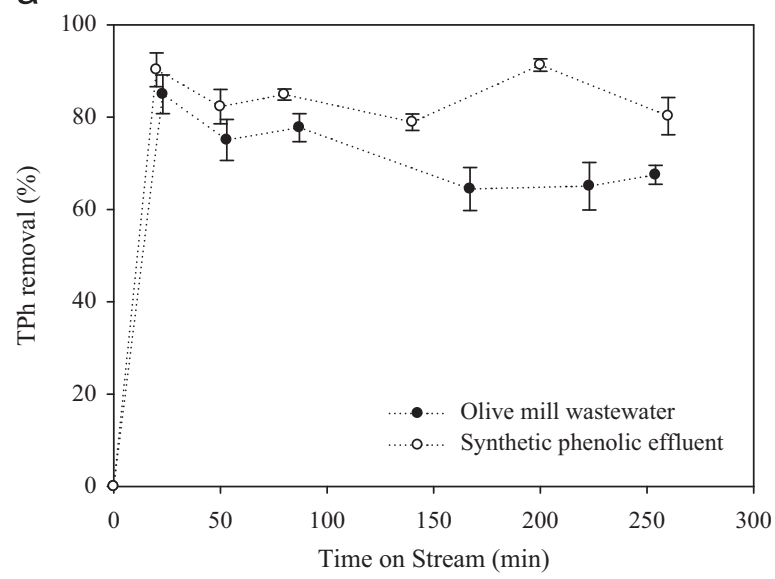

b

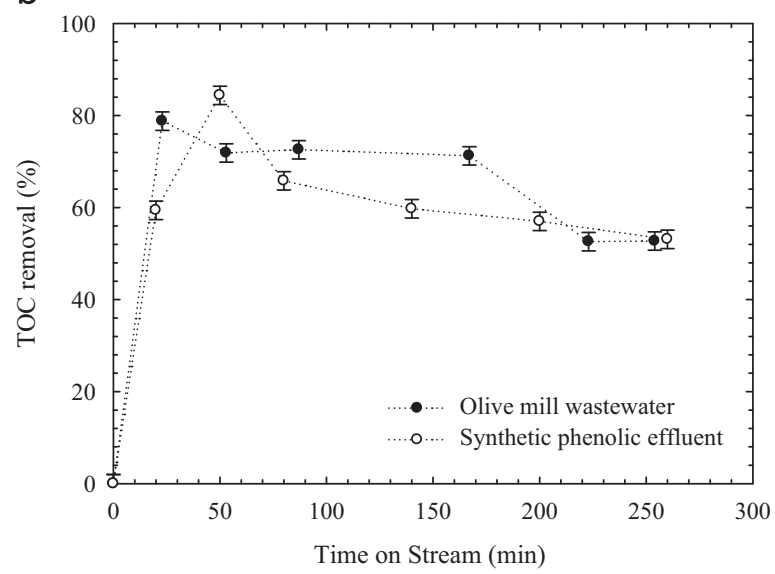

C

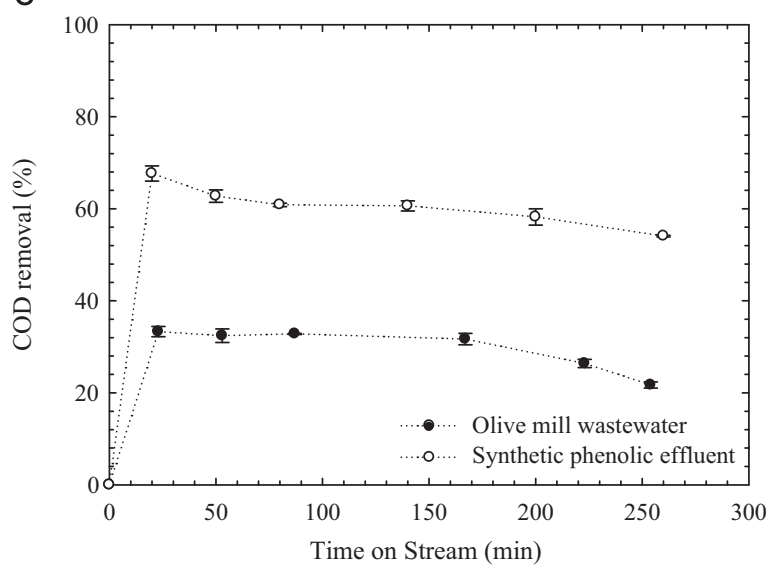

Fig. 10. Comparison between the behavior of the continuous fixed bed reactor when treating the simulated and the actual olive mill wastewater regarding (a) TPh, (b) TOC and (c) COD removal.

Fenton's over ZVI process showed also activity in continuous conditions in a fixed bed reactor. In fact, high removals of $88.3 \%$, $84.8 \%$ and $62.8 \%$ were attained in terms of TPh, TOC and COD abatement, respectively. Even if a decrease on efficiency was detected after $168 \mathrm{~h}$ of operation in the column, TPh, TOC and
COD removals of about $73,39 \%$ and $44 \%$, respectively were still possible. Similar results were achieved when a real olive mill wastewater was used, but it was concluded that an efficient coagulation/flocculation system must be previously applied since some solids precipitation occurred leading to the reactor clogging.

These results indicate that iron shavings, being a waste of iron industry, are promising low cost catalytic materials to be used in Fenton's reaction for the treatment of bio-refractory effluents, namely olive mill wastewater, in batch or continuous operations.

\section{Acknowledgments}

The authors thank Fundação para a Ciência e Tecnologia by the financial support under the Contract (PTDC/EQU-ERQ/113308/ 2009). Rui C. Martins gratefully acknowledges Fundação para a Ciência e Tecnologia by the post-doc Grant (BPD/72200/2010).

\section{References}

Bautista, P., Mohedano, A., Casas, J., Zazo, J., Rodriguez, J., 2008. An overview of the application of Fenton oxidation to industrial wastewaters treatment. J. Chem. Tech. Biotechnol 83, 1323-1338.

Bremmer, D., Burgess, A., Houllemare, D., Namking, K., 2006. Phenol degradation using hydroxyl radicals generated from zero-valent iron and hydrogen peroxide. Appl. Catal. B 63, 15-19.

Chu, L., Wang, J., Dong, J., Liu, H., Sun, X., 2012. Treatment of coking wastewater by advanced Fenton oxidation process using iron powder and hydrogen peroxide. Chemosphere 86, 409-414.

Deng, Y., Englehardt, J., 2008. Hydrogen peroxide-enhanced iron-mediated aeration for the treatment of mature landfill leachate. J. Hazard. Mater. 153, 293-299.

Eckenfelder, E. 1989, Industrial water pollution control, McGraw-Hill, 2nd Edition, Singapore.

Esplugas, S., Contreras, S., Ollis, D., 2004. Engineering aspects of the integration of chemical and biological oxidation: simple mechanistic models for the oxidation treatment. J. Environ. Eng. 130, 967-974.

Folin, O., Ciocalteu, V., 1927. On tyrosine and trytophane determination in proteins. J. Biol. Chem. LXXXI, 627.

Kallel, M., Belaid, C., Mechichi, T., Ksibi, M., Elleuch, B., 2009. Removal of organic load and phenolic compounds from olive mill wastewaters by Fenton oxidation with zero-valent iron. Chem. Eng. J. 150, 391-395.

Martins, R., Rossi, A., Quinta-Ferreira, R., 2010. Fenton's oxidation process for phenolic wastewater remediation and biodegradability enhancement. J. Hazard. Mater. 180, 716-721.

Martins, R.C., Lopes, D.V., Quina, M.J., Quinta-Ferreira, R.M., 2012. Treatment improvement of urban landfill leachates by Fenton-like process using ZVI. Chem. Eng. J. 192, 219-225.

Neyens, E., Baeyens, J., 2003. A review of classic Fenton's peroxidation as an advanced oxidation technique. J. Hazard. Mater. 98, 33-50.

Ramirez, J., Maldonado-Hódar, F., Pérez-Cadenas, A., Moreno-Castilla, C., Costa, C., Madeira, L., 2007. Azo-dye orange X degradation by heterogeneous Fenton-like reaction using carbon-Fe catalysts. Appl. Catal. B 75, 312

Rodríguez, A., Ovejero, G., Sotelo, J., Mestanza, M., García, J., 2010. Heterogeneous Fenton catalyst supports screening for mono azo dye degradation in contamined wastewaters. Ind. Eng. Chem. Res. 49, 498-505.

Silva, A., Nouli, E., Carmo-Apolinário, A., Xekoukoulakis, N., Mantzavinos, D., 2007. Sonophotocatalytic $/ \mathrm{H}_{2} \mathrm{O}_{2}$ degradation of phenolic compounds in agroindustrial effluents. Catal. Today 124, 232.

Soon, A., Hameed, B., 2011. Heterogeneous catalytic treatment of synthetic dyes in aqueous media using Fenton and photo-assisted Fenton process. Desalination 269, 1-16.

Standard Methods for the Examination of Water and Wastewater, 1992. APHA AWWA,WPCF,18th ed., Greenberg, A., Clesceri, L., Eaton, A. (Eds), American Public Health Association ,Washington DC.

Valdés, H., Murillo, F., Manoli, J., Zaror, C., 2008. Heterogeneous catalytic ozonation of benzothiazole aqueous solution promoted by volcanic sand. J. Hazard. Mater. 153, 1036-1042.

Xu, L., Wang, J., 2011. A heterogeneous Fenton-like system with nanoparticulate zero-valent iron for removal of 4-chloro-3-methyl phenol. J. Hazard. Mater 186, 256-264.

Zhao, Z., Jiang, J., Huang, Y., Yang, Y., 2006. Zero-valence iron process treatment of landfill leachate. J. Tsinghua Univ. (Sci. Technol.) 46, 1987-1990. 